doi: https://doi.org/10.15407/microbiolj80.04.108

УДК 633:582.4:579.328+577.1

\title{
PHYTOPLASMOSIS OF BIOENERGY CULTURES
}

\author{
A. Brzozowska', M. Dacko', A. Kalinichenko ${ }^{3}$, \\ V.F. Petrychenko ${ }^{4}$ I. P. Tokovenko ${ }^{5}$ \\ ${ }^{1}$ Czestochowa University of Technology, \\ 19 B Armii Krajowej, Czestochowa, 42-200, Poland \\ ${ }^{2}$ University of Agriculture in Krakow, \\ 21 Al. Mickiewicza, Kraków, 31-120, Poland \\ ${ }^{3}$ University of Opole, 1/3 Dmowskiego str, Opole, 45-365, Poland \\ ${ }^{4}$ Institute of Feeds and Agriculture of Podillia of the NAAS of Ukrain, \\ 16 Yunotsi Avenue, Vinnitsa, 21100, Ukraine \\ ${ }^{5}$ Zabolotny Institute of Microbiology and Virology, NAS of Ukraine, \\ 154 Akad. Zabolotny Str., Kyiv, 03143, Ukraine \\ e-mail: akalinichenko@uni.opole.pl; tira@bigmir.net
}

\begin{abstract}
The current state of biofuel distribution in EU, USA and Ukraine and its perspectives, new alternative sources of renewable energy, advantages and disadvantages of their use have been analyzed in this review. The concept growing of energy cultures in Ukraine has been described. Prospects for the use of bioenergy cultures of the 2nd generation have been considered. Particular attention has been paid to advantages and peculiarities of growing cultures with high potential of productivity - willow and poplar. The role of phytoplasmas in plant pathology has been considered; the pathways of distribution of plant phytoplasmosis, their localization in plant-host cells, typical symptoms of plants affected phytoplasmal diseases have been described, as well as attention has been paid to the distribution of phytoplasmas in Europe and Ukraine, which are capable to affect the perspective bioenergy cultures of wood species.
\end{abstract}

Keywords: biofuels, renewable sources, phytoplasma, phytoplasmosis, bioenergy cultures, willow, poplar.

The use of raw material resources of the Earth have been carried out for many centuries, but only in the second half of the XX century, many countries with different levels of development and different political structure, faced with a real and sometimes critical deficit of oil, gas and other types of minerals [1-3].

In recent decades, the share of fossil fuels in providing world needs has reached $88-89 \%$. Such limitation of the stock of raw materials has become so evident that the future prospects for the existence of civilization are based on the need for the transition of the economy to the resources of the biosphere, which, unlike fossil fuels, are regenerative. Plant biomass is an essential component of the raw material resources of the biosphere, and due to the mechanism of photosynthesis and the practical unlimited solar energy reproduced every year on a huge scale. However, the availability of biomass in sufficient quantities does not alone provide a solution to the problem. The problem of environmental protection is closely linked with the problems of modern energy. 
Modern energy is based on the combustion of petroleum products, coal and natural gas, which clogs the atmosphere with a huge amount of $\mathrm{CO}_{2}$, other greenhouse gases and acid-forming oxides of nitrogen and sulfur. Huge emissions of carbon dioxide and methane to the atmosphere lead to an increase in the greenhouse effect, causing direct damage to the environment, which leads to climate change on the planet [1-3]. So, the energy problem becomes global and has all the signs of the ecological crisis. This prompts scientists to immediately search for reliable, alternative, constantly renewable sources of energy [1-4]. Due to this, renewable energy is one of the most discussed topics in Europe and in the world.

Current state of distribution of biofuels in the EU, USA and Ukraine and its prospects. In recent years, both in the world and in Ukraine in particular, in connection with the rise in energy prices, more and more attention has been paid to biofuels produced from high-energy cultures.

The production of biogas is an effective and investment-attractive technology, which is conditioned by the presence of significant raw material potential, favorable natural and climatic conditions and low cost of this type of energy compared with the production of bioethanol and biodiesel [3].

However, Ukraine is at the initial stage of the introduction of renewable energy sources, the scientific and technical and economic problems of the production and use of biogas are not sufficiently studied [3].

Biogas technology leaders are such countries as Germany, the United Kingdom, USA, Canada, Brazil, Denmark, China, India and others [3]. So, in Poland, according to the renewable energy development strategy, it is anticipated that for achivement $20 \%$ of the share of alternative fuels in transport by 2020 will be build 26 biofuel plants with capacity from 25 to 150 thousand tons of fuel per year [5 -7]. In order to increase the interest of biofuels producers, the legislation of Poland provides for a number of incentives (state supplements, preferential excise rates for mixed fuels containing biofuels, simplified procedures for obtaining biofuel production permits, etc.) [5 - 7].

In Germany, there are 29 biodiesel and 3 bioethanol high-performance plants producing about 2 million tons of biofuels. In the long run, the number of such enterprises will be brought to 40 biodiesel and 60 bioethanol plants [5-7].

For Ukraine, the strategic goal of which is integration into the EU, the development of bioenergy is of particular importance, since the use of renewable energy sources is not lower than the average European level - one of the requirements of the European Union to the candidate countries, which is an additional argument in favor of the development of renewable energy sources [8].

In 2009, the EU directive on greenhouse gas emission reductions has been adopted, which stated that installations after 2008 should ensure reduction of greenhouse gas (GHG) emissions by 35\%, from 2017 - 50\%, from $2018-60 \%$ [9 - 17].

For a long time, the policy to stimulate the use of biofuels in the EU has been an important source of demand for Ukrainian suppliers of raw materials $[18,19]$. 
By committing itself to reducing greenhouse gas emissions under the Kyoto Protocol and trying to reduce its dependence on the import of traditional energy sources, since 1997, the EU has approved renewable energy targets in the form of its share in final energy consumption $[18,19]$.

The fulfillment of the targets required the introduction of state support for biofuels in transport and renewable energy in general at both the EU level and at the level of legislation of the member states. These programs have led to a gradual increase in production and consumption of biofuels, and hence to an increase in demand for raw materials.

Since biodiesel accounts for about $75 \%$ of the biofuels market in the EU, vegetable oils (rapeseed oil and rapeseed) are the main raw material for its production. Recently, the demand for rapeseed oil and seeds has grown to such an extent that it could not be satisfied with production within the EU, since now in the EU only $45 \%$ of the oil produced from seeds is grown in the $\mathrm{EU}$, and the rest of the raw materials are imported. According to the European Commission, to achieve the 2020 targets, about $30 \%$ of the raw materials needed to be imported into the EU should be imported [18].

Ukraine refers to countries that only partially provide themselves with traditional types of energy resources and are forced to import about $65 \%$ of fossil fuels. The modern energy policy of Ukraine is based to a large extent on the import of energy raw materials, the price of which is constantly increasing, and this trend is increasing year after year, as the extraction of fossil energy sources is reduced, and in the near future, the reserves of these energy sources will be exhausted.

In 2001, while renewable energy production dynamically developed in most European countries, within the framework of a joint Ukrainian-Danish project on the activities of non-governmental organizations in the field of sustainable development with the participation of the NGO "Energy of the Future Century" jointly with the Danish "Organization on renewable energy "a document" The Concept of Bioenergy Development in Ukraine "was prepared, in which it was noted that it is now profitable for Ukraine to produce heat from biomass, and the most competitive today, technologies such as wood burning stations of centralized supply, straw burning boilers and biogas plants are capable and promising $[20,21]$.

Therefore, the development of non-traditional and renewable energy sources (NRES) in Ukraine should be considered as an important factor in increasing the level of energy security and reducing the anthropogenic impact of energy on the environment. Despite its dependence on energy imports, Ukraine has paid little attention to the development of NRES, whose share in the structure of energy consumption is $0.8 \%$, which is much lower compared to other European countries.

Energy cultures are a valuable source of biomass. An important component of the EU bioenergy sector is energy cultures - plants that are specially cultivated for direct use as fuel or biofuels [22]. One of the EU's main goals for 2020 is to achieve a biomass share of $14 \%$ of gross final energy use. (Ukraine has a great potential for the production of biomass from vegetable raw materials.) As was reported from Government portal of Cabinet of Ministers (gov.ua), in Ukraine, today, with 32 million hectares of agricultural land, there 
are about 4 million hectares of low-yielding, which can be used to grow energy cultures and thus, Ukraine may potentially replace by energy crops nearly 20 billion cubic meters of gas.

The main priorities of phytoenergy are the search for cheap biomaterials, the creation of the necessary infrastructure for the cultivation of energy plants and the conversion of biomass through chemical or biological processes into different types of biofuels: liquid (ethanol, methanol, butanol, biodiesel), gaseous (methane, synthesis gas, hydrogen), and solid (fuel pellets, briquettes, cod, straw, husk, firewood).

One of the most promising alternative energy sources today is solid biomass of organic origin, including vegetable, which is an environmentally friendly renewable energy source. Biomass energy is equivalent to 2 billion, accounting for about $13-15 \%$ of the total use of primary energy resources in the world. The share of Ukraine, according to some estimates, is about 50 million tons, but the economically feasible potential of biomass is estimated at 27 million. A significant attention in the world is devoted to the problem of biomass processing in order to obtain biofuels. Biomass in power engineering can be used directly by burning or as fuel - after pre-processing on diesel fuel, ethanol or gas.

Consider what raw materials and energy cultures are used to produce biofuels:

For the production of biofuels of the first generation, significant raw materials are needed: energy crops such as canola, sugar beet, corn and others.

Second generation biofuels are required for energy cultures such as miskanthus and tree crops (poplar, willow).

Third generation biofuel production requires energy cultures such as single-cellular algae (chlorella, chlamidomonade), some eubacteria and cyanobacteria.

It should be noted that today the EU Parliament is worried about the high prices of biofuels of the 1st generation, which are no longer considered safe for the environment, and MEPs question its economic viability. Therefore, they will support the production of electric cars and biofuels of the so-called 2nd generation, which are mainly made from wood, as well as straw (cellulose) and algae (3rd generation).

The main advantages of plant biomass, as a source of energy, include the environmental cleanliness of emissions, compared with fossil fuels, the absence of a negative effect on the balance of carbon dioxide in the atmosphere. During the combustion of biofuels on the basis of plant biomass, less carbon dioxide is emitted into the atmosphere than absorbed by plants during photosynthesis, 20-30 times less sulfur oxide and 3-4 times less as compared with coal. The by-product in the process of producing liquid and gaseous biofuels and as a result of the combustion of solid biofuels is an organic substance that can be used as fertilizer.

Perennial energy plants are able to accumulate energy intensively during the growing season due to the favorable soil and climatic conditions of most regions of Ukraine. These plants are characterized by low cost of cultivation, not demanding soil fertility, do not require significant use of fertilizers and pesticides, prevent soil erosion, promote the preservation and improvement of 
agroecosystems. This allows cultivating energy plants on land removed from crop rotation, which, according to statistics in Ukraine, has from 3 to 5 million hectares (Government Portal (gov.ua).

The cultivation of energy crops with high biomass productivity ensures a significant flow of organic matter into the soil by the root system and postbreaks, which contributes to the accumulation of humus compounds in the soil. The lack of mechanical cultivation of soil during the cultivation of perennial crops helps to stabilize the species and quantitative composition of the soil microflora, the course of soil formation processes according to the genetic features of the soil cover.

Energy cultures of the second generation. Advantages and disadvantages of their use. The most up-to-date for Ukraine is the search for non-traditional renewable energy sources, among which energetic plants deserve special attention. The source of energy raw materials can be both byproducts of plant origin and specially designed plants for this purpose, such as willow and poplar [23-28]. Such energetic plants are valuable to a large harvest and unpretentious to cultivation, and the use of plant biomass provided it is continuously restored (for example, new forest plantations after deforestation) does not lead to an increase in the concentration of carbon dioxide in the atmosphere.

A large number of plants have been investigated to determine the potential use of them as energy crops, but only a few species have reached commercial level and are grown in large areas. Among them the most common are: miskanthus, myrchigras, willow, poplars (they are planted about 10-15 - up to 30 years old, the preparation of the soil for their cultivation does not require high energy costs, the harvest is harvested in the winter or in spring using conventional agricultural machinery).

Particular attention should be paid to such promising and most common bioenergetic crops of tree species with high productivity potential, such as willow and poplar. Let's consider their advantages and features of cultivation.

Willow (Salix L.) - a genus of trees or shrubs of the family of willow (Salicaceae). Energy willow - usually thick, grows up to 5-6 m tall and has a large number of shoots. It is quite easily reproduced by vegetative shoots. Willow planting will remain productive up to 25-30 years, and the harvest during this period can be collected in three or four years. From 1 hectare of plantation can receive up to 30-40 tons of dry wood mass each year.

Positive is that the willow is resistant to frost and drought, to pests and diseases, it can grow on different types of soils, in hills, in ravines with high levels of groundwater, in wet lands that provide good water supply, even on unproductive lands which need reclamation, that is, on lands that are unsuitable for agriculture. One ton of willow with $40 \%$ humidity provides $1 \mathrm{Gcal}$ of heat, while the same amount of dry raw material at $15 \%$ moisture gives 2 Gcal of heat.

Approximately after 25 years, the use of willow is eradicated, and the land is used to grow other crops or spend new plantings of energy plants. Culture has a great potential for productivity, especially in lowland and fertile lands with good water supply, which are the most acceptable. Great potential of energy plantations on lands that are not used or used inefficiently. In the end, energy willow can significantly contribute to solving not only energy, but also environmental problems associated with the treatment of sewage [ 23 - 27]. 
Poplar (Populus) - the family of the willow (Salicaceae). Poplar is a close relative of willow, which also found its application in bioenergy. Like the willow, it is grown in Western Europe for heating. In our climatic conditions among all other trees, the poplar itself grows fastest. It grows in similar conditions with willow. For its growth needs a lot of moisture and light. Therefore, the largest yield of biomass will be in conditions close to those in the valleys of the rivers.

Poplar has long been used as an energy crop due to its rapid growth and resistance to pests and the possibility of growing on poor soils. For the most part, it does not require the use of pesticides and fertilizers. The possibility of its cultivation on contaminated lands is revealed [28].

Recently, due to relatively rapid growth and the formation of biomass, poplar stands are increasingly used as regenerative energy sources for biofuel production. Its wood is fairly light, widely used for technical purposes.

Four cubic meters of wood replace $1000 \mathrm{~m}^{3}$ of gas. Such biofuel will cost the state almost four times cheaper. Poplar absorbs a large amount of carbon dioxide, thanks this we can get environmentally friendly fuel. Hazardous emissions, compared with diesel fuel, will be reduced by $90 \%$. In industrial plantations, the dry mass yield of poplar is up to $6-12 \mathrm{t} / \mathrm{ha}$. Poplar plantations remain productive up to 15-20 years or more, and biomass can be harvested every three to six years during this period.

Like other power plants poplar can also grow on marginal soils unsuitable for food production, minimizing competition between food crops and bioenergetic.

An overview of the practice of growing energy plants in the $\mathrm{EU}$ and in the world. Among all the energy plants in the world, willow today is used in the world as the main energy crop for the production of solid fuels. The most rapid development in the field of phytoenergy, this culture has acquired in the Scandinavian countries, it is recommended to grow on wetlands and low productive land. Biomass of energy willow in the form of fuel cod is the main raw material for the production of green energy at thermal stations in Denmark, Belgium, Finland, England, Germany, Austria and Poland. Sweden has made significant success in growing willow on soils, which for several decades increases crop area, which today is about 18,000 to 20,000 hectares. So, energy crops are an important part of the EU bioenergy sector.

The European Bioenergy Association (AEBIOM) estimates the current potential of energy crops in the European Union at a level of 44-47 million tons / year. One of the EU's goals for 2020 is to reach 138 million tons in the year. Biomass in gross final energy consumption is correspond to $14 \%$ of VCE. Existing potential of energy crops can cover about a third of this target. In 2011, the total area under ligno-cellulosic energy crops in the EU is about 130140 thousand hectares (Table 1). About $37 \%$ of this area (50 thousand hectares) falls to Romania, where the millet is grown as rodlike. Significant areas are also used in Finland under digitaria arundinacea (about 19 thousand hectares), in the UK - under the miskanthus (10-11 thousand hectares), in Sweden and Poland under willow (11 thousand hectares and 5-9 thousand hectares, respectively).

The first industrial willow plantations of energy appeared in Sweden in the late 80 's - early 90 's of the last century, when the trend of using alternative energy sources instead of traditional and well-known oil and gas began to emerge in Europe. Therefore, Sweden is rightfully considered to be the country 
Areas under lignocellulosic energy cultures in the EU (2011), ha

\begin{tabular}{|l|c|c|c|c|c|}
\hline EU countries & Willow & Poplar & Miskanthus & Millet & $\begin{array}{c}\text { Digitaria } \\
\text { arundinacea }\end{array}$ \\
\hline Austria & $220-1100$ & $880-1100$ & 800 & & \\
\hline Belgium & 60 & & 100 & & \\
\hline UK & $1500-2300$ & & $10000-11000$ & & \\
\hline Germany & 4000 & 5000 & & 2000 & \\
\hline Denmark & 5697 & 2807 & & 64 & \\
\hline Ireland & 930 & & & 2200 & \\
\hline Italy & 670 & 5490 & & $50-100$ & \\
\hline Lithuania & 550 & & & & \\
\hline Netherlands & & & & & \\
\hline Poland & $5000-9000$ & 300 & & & \\
\hline Romania & & & & 50000 & 780 \\
\hline Sweden & 11000 & 550 & & & \\
\hline Finland & & & & $2000-3000$ & \\
\hline France & & 2300 & & & \\
\hline
\end{tabular}

that first proposed and implemented the industrial technology of growing energy willow as a solid biofuel. The following countries, which began to follow the example of Sweden, were Britain, Ireland, Denmark, Poland, the USA and others. In 2008, the first industrial landings appeared in Ukraine. The proliferation of this long-term culture in these countries is due, first of all, to favorable climatic conditions for its cultivation. This is a sufficient amount of precipitation, the volume of which should be less than 550-600 $\mathrm{mm}$ per year to achieve the planned yields. Of course, in addition to energy willow, there are many other plants that are grown to produce green biomass, but they are common in other geographic areas that are best suited for their reproduction. Despite the fact that the main purpose of energy willow is biofuels for the production of electricity and heat, different countries have their own specifics of the use of biomass from energy plantations of willow and main market drivers.

Sweden. According to various estimates, willow in Sweden is grown on an area from 15 to 20 thousand hectares. According to Lantmännen, on average, approximately 500 hectares of new plantations annually are planted in the country, and the same number is re-cultivated. Plantation owners and producers of energy cod are ordinary farmers. The main driving forces behind the development of this market are the high carbon dioxide emission tax (70 euros / $t$ ) and the high demand for biomass inside the country, due to the large number of district heating projects that operate on solid biofuels. Pellets are supplied to 25 heat generation facilities. By this indicator, Sweden is in the first place in the world. Today, only 5\% of energy in Sweden comes from oil. Another important factor in growing plantations is the state support of farmers in this direction. Covering part of the cost of creating plantations is at a rate of 500 euros per 1 hectare. All these measures have contributed to the fact that Sweden has become a global leader in this segment of bioenergy. Thus, it has reduced the import of expensive energy resources and switched to the use of domestic alternative energy sources. The country showed how in a short period 
of time it is possible to completely change the structure of energy consumption, thus creating additional jobs.

UK. According to the European Biomass Association (AEBIOM), about 4,000 hectares of willow plantations are planted in the UK. In this country, energy from willow will be used mainly as a biofuel in the CHP, which creates the appropriate legal conditions. Among the main factors contributing to the development of plantations in the UK, one can distinguish the limited forest resources in the country and the state support of farmers at a rate of 800-1000 pounds sterling per hectare (compensation part of landing costs).

Denmark. Despite its small size, this country is at the forefront of bioenergy development. In recent years, there have started to build new district heating plants using solid biofuels, which are considered by other countries as an example for imitation. One of the energy sources of such plants is plantations of energy willow, with an area of over 3,000 hectares in Denmark. Unlike other countries, high prices for biomass have become a major stimulus for farmers, which in turn is driven by high demand within the country. As of 2012, energy willow prices in Denmark are approaching $€ 100 / \mathrm{t}$.

Poland. According to the Agency for Restructuring and Modernization of Agriculture (ARiMR), more than 6,000 hectares of energy willow were planted in Poland in 2010. The main demand for biomass from these plantations is formed by the Polish TPPs, which produce $90 \%$ of the electricity in the country. Therefore, a law was passed in Poland that encourages TES to use, along with coal, biofuels to reduce $\mathrm{CO}_{2}$ emissions into the atmosphere. The fact that in 2008 Poland adopted a decree encouraging the use of agricultural biomass, which includes energy plants, was also positive for the market. According to this regulation, objects that consume biofuels must be guaranteed to use the minimum set percentage of agrobiomas. The relevant indicators are set for different categories of producers of thermal and electric energy, which implies an increase in the consumption of agrobiomas by 2017. The adoption of the aforementioned decree and the presence of a large number of unproductive land gave impetus to the development of energy willow plantations in Poland. So, there was a good practice in the country that could be taken as a basis for the development of the bioenergy market in Ukraine.

Energy companies are ready to partially finance plantations and guarantee the purchase of all biomass in future years. Taking into account that in Ukraine the share of coal use in generating electricity is large, only a 5-degree substitution of coal with biomass or co-firing can give a big impetus to the development of the domestic market for solid biofuels. This is more beneficial than building new biomass plants, because it requires less investment to modernize equipment. Replacement of 5\% of coal for biofuels at Ukrainian TPPs is a market in volume of 1.5-2 million tons of pellets, which is 3-4 times more than it is produced as of 2012 .

The concept of growing energy cultures in Ukraine. Among all energy plants in the world, it is the willow used as the main energy culture for the production of solid fuels. The experience of "green" energy (as already reported above) are Norway, Denmark, Germany, Austria, Poland, England and Ireland. The greatest successes in this area are demonstrated by Sweden. Here plantations of willow occupy more than 20 thousand hectares, and from it they receive raw materials even for heating plants. 
Ukraine is laying only the first trees of the energy "grove". The energy potential of biomass, which is in Ukraine in different forms, is 24 million tons of conventional biofuels per year.

However currently using only $2 \%$. When cultivating energy crops, costs per equivalent energy are tens of times lower compared to the cost of energy from traditional sources. Undoubtedly, the positive impact of energy crops on the preservation and reproduction of ecosystems helps to eliminate the problems associated with environmental pollution, minimizes the trends of global warming.

Today in Ukraine there are also several companies engaged in the cultivation of energy crops at a commercial level. Another number of companies are planning to enter this market in the near future. The "Salix Energy" company, which was founded in 2010, has the largest energy willow plantations in Ukraine (Salix Viminalis), located in the Volyn and Lviv regions (> 1500 ha). 6 varieties of willow are harvested, including Polish and Swedish. In 2013, the company registered its own brand "Marciana" (the only one officially registered in Ukraine). For 2014-2015 there are plans to expand willow plantations to 2,53 thousand hectares and start of industrial harvesting. Salix Energy plans to harvest energy from willow for the production of thermal and electric energy in Ukraine.

There are also some local programs for the development of energy cultures, such as the Program for growing energy willow seedlings in Rivne region for 2010-2011, approved by the chairman of the Rivne Regional State Administration from June 14, 2010.

But, despite the very active beginning of the development of energy cultures cultivation in Ukraine in recent years, there are a number of problems that require solutions.

One of these problems is spreading of bioenergy cultures diseases caused with phytopathogenic microorganisms and absence of monitoring and diagnosis of these diseases. Moreover, we should not forget that current global trade and its potential for further introductions of wood pathogens may dwarf any improvement in management that derives from such developments.

Many pathogens are affecting trees in different ecosystems, causing ecological and economic problems in various regions of the world. Infectious diseases are caused by a diverse range of phytopathogenic organisms, including fungi, bacteria, viruses and phytoplasmas.

Among the prokaryotes, phytoplasmas cause the greatest economic damage to different species of trees. Phytoplasmas are associated with the diseases of several hundred plant species, including a number of tree species, in many places in the world [29].

Disease agents are infectious, whether on their own or due to a vector, and the diseases which they cause are thus transmissible from diseased to healthy trees.

Therefore, the perfect knowledge of biology of pathogens and epidemiology of any disease remains key in the development of modern, effective and sustainable control strategies, including a comprehensive disease management program.

Unfortunately, quite a small group of phytopathologists who are investigating the pathogens of wood species, and practically there are no studies 
of phytoplasmosis of wood species, in particular such valuable bioenergy species as willow and poplar. Therefore there is a need for a more informed issue on the health of trees throughout the scientific community.

Taking into account the harmfulness and danger of these pathogens, we will consider pathways of distribution of plant phytoplasmosis, and also will consider the role of phytoplasmas in plant pathology, their localization, typical symptoms of plants affected phytoplasmal diseases and also we will pay special attention to the distribution of phytoplasmas in Europe and Ukraine, which are capable to affect the perspective bioenergy cultures of wood species willow and poplar.

Pathways of plant phytoplasmosis dissemination. Causative agent of phytoplasmosis - phytoplasmas, which are lack cell walls with DNA characterized by low guanine and cytosine $(\mathrm{G}+\mathrm{C})$ content. These prokaryotes are typical transmissible pathogens, for the outspread of which vector are required.

The main role in the distribution of phytoplasmosis of plants plays insects, mainly - leafsticks. In these insect-vectors well-persist phytoplasmas. The incubation period for various phytoplasmas in their vectors varies in the depending of vector type and the climatic conditions during its infection. At this case phytoplasmas in a vector multiply and detected almost in all tissues [29]. For certain perennial plant species, mainly - wood species, the preservation of infection in the root part have been also established. So, the hibernation of phytoplasmas in the root part of plants have been demonstrated for such diseases caused with phytoplasmas as phloem necrosis of the elm [32], wilting pears [33], X-disease of the peach [34] and others.

However, phytoplasmas are rarely strictly specialized pathogens. Plants that they affect are determined with the species composition of plants on which the given vector feeds. Area of the spread of the disease, as a rule, is limited with the range of resettlement of the vector. If the disease is transmitted with several vectors, area of its distribution is the sum of ranges of each vector. Plants, on which feed a large number of leafsticks species can be affected diseases, which are pathogens of different phytoplasma species. At this case superinfection of plants is observed - simultaneous damage by various pathogens, which often leads to plant death.

\section{Localization and pathogenicity of phytoplasmas, symptoms of plants affected phytoplasmal diseases. \\ Localization of phytoplasmas. Phytoplasmas are usually detected in the} phloem sieve elements of the affected plants.Phytoplasmas accumulate in the phloem sieve tubes of plants and transmitted with insects of the order Hemiptera which feeds onto these plants [35]. Sometimes they are detected also in parenchyma cells, as well as in tissue cells that are nearby with phloem and with core parenchymal tissues. Pores of sieve vessels and plasmodesma are the pathways of phytoplasma transition from cell to cell.

Obviously, at strongly inhabited cells of different tissues of plants by phytoplasmas, there is a significant violation of normal processes, not only in separate cells, but also in whole systems of tissues. Even if cells are not inhabited by phytoplasmas, but are in the nearness of an infected or in a systemic connection with them, then they lose the normal structure and functions under the influence of various factors of phytoplasmas pathogenicity. 
But in woody host, the phytoplasmas concentration is often low and may be below the level of microscopical detection [36].

Pathogenicity of phytoplasmas. Different methods have been used to prove pathogenicity of the agents and to establish their belonging to the class Mollicutes (family: Acholeplasmataceae) such as: cultivation in the artificial nutrient medium, investigation of the mycoplasma properties in the pure culture, infection of plants with pure culture of this pathogen, establishment fixation of the antigenal relationship of isolated agents with some phytoplasma species.

Pathogenicity of phytoplasmas in single infected plants is very high. As a result of infection with phytoplasma - infected plants can not grow and develop normally.

What is the possible explanation of the phytoplasma aggressiveness in plants? Prof. Vlasov assumed that cultivated plants are just accidental hosts of the phytoplasma [37]. If this is true, they hare seriously affected by infection agents.

There are cases when wild plants without showing symptoms of the disease. Such latent infection carriage was probably developed as a results of a long term coevolution of the pathogene and its host. The aggressive properties of the pathogen have immediately become apparent by the transmitting of the infection on new host.

It should be noticed, that the insects, which are vectors of the phytoplasmas are not only carriers but the main host of phytoplasmas as well. Relations between phytoplasmas and insects in most cases resemble the symbiotic ones. Cultured plants are infected by the phytoplasmas when they get in the natural nidus of the infection and when the conditions for the pathogens transmission from the natural nidus are favourable.

There may be some more explanations of the high phytoplasma pathogenicity in case of natural transmission of infection for plants. Phytoplasmas while cultivating in the pure culture as well as other microorganisms may partially lose their pathogenicity. This fact doesn't allow investigators to put special attention to the high phytoplasma aggressivity when they infect cultured plants under the natural conditions. That is, there is observed certainly high aggressivity of phytoplasma infection to plants but there was no attempt to look for pathogens among representatives of Acholeplasmataceae family. Thus, the establishment of the role of phytoplasmas in pathology of plants requires further research. Obviously that new experimental data will help to recognize and identify new diseases caused by phytoplasmas [37].

Symptoms of plants infected with phytoplasmosis. The inhabited of cells of various tissues of plants by phytoplasmas leads to the fact that plants affected phytoplasmal disease become dwarf, yellowish. Occasionally the plants affected phytoplasmosis become stifled, and with superinfection - often die. Damage to plants by phytoplasmosis violates the processes of regulation of growth and development, leads to changes in the habit of the plant. In this case, the adventitious kidneys and offshoots are formed in excess, disturbed domination of the tops. Due to the presence of numerous additional offshoots, the plant has the form of «witches,» becomes dwarf. In these plants, the internodes are shortened, the size of the leaves is diminished, and the insignificant 
slowed growth rate. Violation of regulatory processes in the plant leads to the appearance of phyllodium in plants distorted development of the generative organs and their infertility. Fruit production of the plant after its lesion by phytoplasmosis stops, since generative organs become vegetative [37].

Symptoms trees affected with phytoplasmosis. The symptoms of diseased plants vary with the phytoplasma, host, stage of disease development, age of host and environment at the time of infection [30, 31, 38].

These symptoms include yellowing or reddening of the foliage, small leaves, leaf curl, vein necrosis and often premature fall coloration. Premature defoliation, poor terminal growth, dieback and decline in plant health are also often reported as being associated with phytoplasmal infection. White ash (Fraxinus americana L.), green ash and velvet ash (Fraxinus velutina Torr.) are the only ash species that have been observed sufficiently to allow comment on phytoplasmal infection symptoms.

Thus, typical symptoms include slow growth, diminished apical dominance, suppressed root development, witches' brooms and subnormal greenness of foliage with early foliage colour change [39, 40].

Scientists who are investigating phytoplasmosis of plants know that the same pathogen can cause disease with different types of signs and, conversely the same type of disease can be caused by different pathogens and that the symptoms of the host plant are not always possible to diagnose the disease and identifying its pathogen.

Only with the advent of molecular biology and using molecular biological methods significant progress was made to understand the biology of these pathogens.

Based on housekeeping genes such as 16S rRNA phytoplasmas have been shown to belong to the class Mollicutes [31, 41 - 45].

For the identification, differentiation and preliminary classification of phytoplasmas, primer pairs based on the highly conserved 16S rRNA gene sequence have been developed. Using the restriction fragment length polymorphism (RFLP) analysis of the 16S rRNA gene, Lee et al. (1993) constructed a classification scheme for phytoplasmas [46].

This scheme, with periodic updates [31, 47-49] has provided reliable markers for the identification and classification of many phytoplasmas into groups and subgroups. In addition, the sequence information from the 16S rRNA genes has served as a baseline for the delineation of 'Candidatus Phytoplasma' candidate species as recommended by the Phytoplasma Taxonomy Group of the International Research Program on Comparative Mycoplasmology (IRPCM Phytoplasma/Spiroplasma Working Team -Phytoplasma Taxonomy Group, 2004) [50].

Distribution of phytoplasmosis among bioenergy cultures. In recent years, in all countries of the world - both in European countries, including Ukraine and in the United States are rapidly spreading phytoplasmosis of wood species which cause the greatest economic damage to many of them [51 - 60].

Using the 16S rRNA gene polymorphic restriction fragment length analysis (RFLP), it has been possible to identify a number of phytoplasmas which are usually found in temperate forests. Using this method it was possible to identify phytoplasma series which are usually found in temperate forests [46]. 
Such promising bioenergy crops like willow and poplar are also affected with phytoplasma - phytoplasmosis agents (Table 2).

So, since 1997, with the use of molecular methods (namely - polymorphic analysis of the restriction fragment length (RFLP) of the 16S rRNA gene) were recorded cases of poplar diseases such as yellowing aster caused with phytoplasmas in such countries as Germany, France, Hungary, Croatia [61 - 63]. It should be noted that different poplars Populus alba L., $P$. nigra $L$., P. tremula $L$., which were infected with phytoplasmas belonged to the same group - 16Srl group (subgroup P) or to AY (Aster Yellows) group ( Ca. Phytoplasma asteris) (Table 2).

Using the same molecular tools (polymorphic analysis of restriction fragment length (RFLP) gene of 16S rRNA, 2009) in China (Shaanxi Province) Wei (2009) showed that trees of willow were infected with phytoplasmas [64]. These scientists identified the phytoplasma disease of the willow, called the Yellows-type disease of salix and found that phytoplasma causing a yellowwillow disease belongs to the group 16Srl (subgroup C) ( $\mathrm{Ca}$. Phytoplasma aster) [64] (Table 2).

So, after analyzing the above it becomes obvious that the phytoplasmas causing disease of willow the type of yellow belong to the same group (16 $\mathrm{Srl})$ as phytoplasmas, which causes the poplar diseases type of yellowing of the aster - 16Srl group ( $\mathrm{Ca}$. Phytoplasma asteris).

Moreover, recently, in 2011 Jomantiene with colleagues [65] found that in Ukraine larch are infected with phytoplasmas.

Table 2

\section{Phytoplasmas commonly detected in temperate forest tree species}

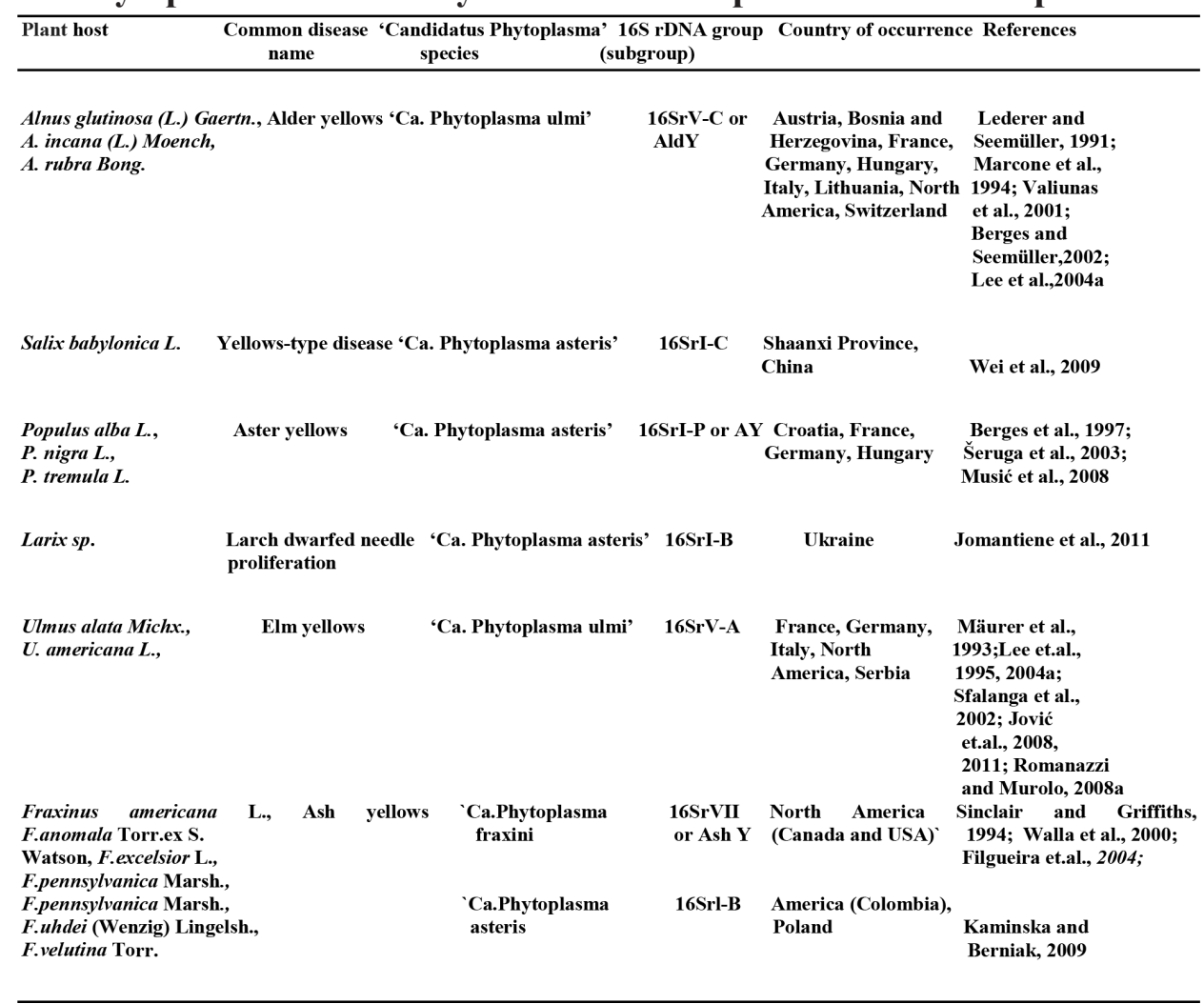


As larch is widely distributed throughout Eurasia and is highly valuable its timber, this finding could have significant economic impact on the timber industry [66]. As the western juniper [67] and the trees in the study reported by Schneider et al. (2005) [68] showed symptoms that often result in tree mortality, these phytoplasmas are likely to be important gymnosperm pathogens. Jomantiene with colleagues [65] identified phytoplasma in Larch (Larix sp.) that caused its proliferation (Larch dwarfed needle proliferation) and determined that this phytoplasma belongs to the same group of $16 \mathrm{Srl}$ (subgroup B) as the phytoplasma that was detected in infected willow and poplar species.

In addition, in Poland, when was observed European ash, trees with symptoms of yellow disease (Ash yellows) of the of ash (Fraxinus excelsior L.) were revealed that were similar to the symptoms described by Sinclair with colleagues - the slow growth and stifled of many types of ash (Ash yellows) [40] (Table 2). However, Polish researchers Kaminsky and Bernyak (2009) first discovered that the phytoplasma that infected ash trees in Poland was a member of the 16SrI ( $\mathrm{Ca}$. Phytoplasma asteris) group, in contrast to the phytoplasmas that were identified in the United States by Sinclair and colleagues (1996) and classified as Group 16SrVII or Ash Y [40, 69].

Thus, in bioenergy cultures - willow and poplars were revealed phytoplasmas that cause yellows-type diseases (yellows of aster) and established that these pathogens belong to the same group - 16Srl ( ' Ca. Phytoplasma asteris ').

In addition, phytoplasmas from this group - 16Srl ( $\mathrm{Ca}$. Phytoplasma asteris ') are able to affect not only the willow and poplar, but also other valuable trees species. So, phytoplasmas from this $16 \mathrm{Srl}$ group are detected both in Ukraine (proliferation of larch) and in Poland (Ash yellows) [40, 69] (Table 2).

The gathered data still require further analysis, but already now, analyzing these data, can be assert that phytoplasmas from the 16Srl group are not likely to be specialized until of certain host plants and therefore these pathogens have more possibilities for survival in nature, as well as for their distribution and, accordingly, infecting with phytoplasmas from this group of $16 \mathrm{Srl}$ of more plants.

To solving this problem, it is necessary to develop effective measures of protection against phytoplasmosis. But now, at the present time measures to protect trees from phytoplasmosis are still limited to agrotechnical measures and the fight against vector insects.

Therefore healthy planting material, healthy seedlings - the main condition for preventing the occurrence of phytoplasmosis of wood species.

Although the future of biofuels is not very clear in Ukraine today, it is hard work to create a biofuel industry in fact de novo and to develop new approaches to the production of biofuels of the 2 nd generation, whose revenues are expected already in 2025.

European scientists are confident in a quick triumph of biofuels, and simple willow and poplar will play their role in the near future. Ukraine has favorable conditions for the development of energy crop production: agrarian development, favorable soil and climatic conditions, availability of free areas of lowproductivity land, the urgency of introducing energy efficiency and environmental approaches in rural areas. 
We would like to hope that in the near future, both in Poland and Ukraine, there will be companies that will begin to grow healthy planting material of energy cultures of such tree species as willow and poplar and the process of mass laying of industrial plantations of these cultures will begin.

\title{
ФІТОПЛАЗМОЗИ БІОЕНЕРГЕТИЧНИХ КУЛЬТУР
}

\author{
А. Бэнозовська ${ }^{1}$ М. Дацко ${ }^{2}$, А. Калініченко \\ В.Ф. Петриченко \\ ${ }^{1}$ Політехніка Ченстоховська, вул. Армії Крайової, 19 В, Ченстохова, 42-200, Польща \\ ${ }^{2}$ Краківський аграрний університет , вул. Мічкевича, 21, Краків, 31-120, Польща \\ ${ }^{3}$ Опольський університет, вул. Дмовського, 1/3, Ополе, 45-365, Польща \\ ${ }^{4}$ Інститут кормів та сільського господарства Поділля НААН Украӥни, \\ проспект Юності, 16, Вінниия, 21100, Україна \\ ${ }_{5}^{5}$ Інститут мікробіології і вірусології ім.Д.К. Заболотного НАН Украӥни, \\ вул. Акад. Заболотного, 154, Київ, 03143, Україна

\section{Резюме}

В огляді проаналізовано сучасний стан поширення біопалива в країнах $\mathrm{CC}$, США та Україні та його перспективи, приділена увага аналізу нових альтернативних джерел відновлювальної енергії, перевагам і недолікам їх використання, викладена концепція вирощування енергетичних культур в Україні. Розглянуті перспективи використання біоенергетичних культур 2-го покоління. Особлива увага приділена перевагам та особливостям вирощування культур з великим потенціалом продуктивності - верби і тополі. Розглянуті шляхи розповсюдження фітоплазмозів рослин, а також розглянута роль фітоплазм в патології рослин, їх локалізації в клітинах рослини-хазяїна, типові симптоми уражених фітоплазмозом дерев, а також приділена увага розповсюдженню в країнах Європи та Україні фітоплазм, які здатні уражувати перспективні біоенергетичні культури деревних порід.

Ключові слова: біопаливо, відновлювальні джерела, фітоплазма, фітоплазмоз, біоенергетичні культури, верба, тополя.

\section{ФИТОПЛАЗМОЗЫ БИОЭНЕРГЕТИЧЕСКИХ КУЛЬТУР}

\section{А. Бжсозовська 1 , М. Дацко ${ }^{2}$, А. Калиниченко В.Ф. Петриченко ${ }^{4}$ И.П. Токовенко}

\footnotetext{
${ }^{1}$ Политехника Ченстоховская, ул. Армии Крайовой, 19 В, Ченстохова, 42-200, Польша

${ }^{2}$ Краковский аграрный университет, ул. Мичкевича, 21, Краков, 31-120, Польша

${ }^{3}$ Опольский университет, ул. Дмовского, 1/3, Ополе, 45-365, Польша

${ }^{4}$ Институт кормов и сельского хозяйства Подолья НААН Украины, проспект Юности, 16, Винница, 21100, Украина

${ }^{5}$ Институт микробиологии и вирусологии им.Д.К. Заболотного НАН Украины, ул. Акад. Заболотного, 154, Киев, 03143, Украина
}

\section{Резюме}

В обзоре проанализировано современное состояние распространения биотоплива в странах ЕС, США и Украины и его перспективы, уделено внимание анализу новых альтернативных источников возобновляемой энергии, преимуществам и недостаткам их использования, изложена концепция выращивания энергетических культур в 
Украине. Рассмотрены перспективы использования биоэнергетических культур 2-го поколения. Особое внимание уделено преимуществам и особенностям выращивания культур с большим потенциалом производительности - ивы и тополя. Рассмотрены пути распространения фитоплазмозов растений, а также рассмотрена роль фитоплазм в патологии растений, их локализации в клетках растения-хозяина, типичные симптомы пораженных фитоплазмозом деревьев, а также уделено внимание распространению в странах Европы и Украины фитоплазм, которые способны поражать перспективные биоэнергетические культуры древесных пород.

Ключевые слова: биотопливо, возобновляемые источники, фитоплазмы, фитоплазмоз, биоэнергетические культуры, ива, тополь.

1. Zolotarova O. Kudy priamuie biopalyvna industriia? Visnyk Natsionalnoi Akademii Nauk Ukrainy. 2010;4:10-20.Ukrainian.

2. Kaliuzhnyi S.V., Puzankov A.E., Varfolomeev S.D. Byohaz: problemy y reshenyia. Byotekhnolohyia. 1988; 21:180. Russian.

3. Holub H.A., Luk ianets S.V. Dosvid vyrobnytstva i vykorystannia biohazu v Polshi Ekonomika APK. 2011; 11:157-61. Ukrainian.

4. Escobar JC, Lora ES, Venturini OJ, et al. Biofuels: Environment, technology and food security Renew. Sust. Ener. Rev. 2009; 13 (6-7):1275 - 87.

5. Kaletnyk H.M. Udoskonalennia pravovoho zabezpechennia funktsionuvannia rynku biopalyva v Ukraini. Aktualni problemy ekonomiky. 2008; 12 (90):48-52. Ukrainian.

6. Kaletnyk H. M. Biopalyvna haluz i enerhetychna ta prodovolcha bezpeka Ukrainy. Visnyk ahrarnoi nauky. 2009; 8:62-4. Ukrainian.

7. Informatsiino-analitychni dovidky//www.ukraineinfo.us

8. Nazarenko A. V. Biopalyvnyi potentsial Ukrainy na svitovomu rynku silskohospodarskoi produktsii. Ekonomika APK. 2010; 1:72-8. Ukrainian.

9. Markevych K., Omelchenko V. Hlobalni enerhetychni trendy kriz pryzmu natsionalnykh interesiv Ukrainy: analit. dop. Kyiv: Zapovit. 2016:118. Ukrainian.

10. Oliinychuk S. Suchasni y perspektyvni tekhnolohii vyrobnytstva biopalyv na svitovomu rynku. Kharchova i pererobna promyslovist. 2009; 6:11-4. Ukrainian.

11. Enerhetychno-resursna skladova rozvytku Ukrainy /Dovhyi S., Yevdoshchuk M., Korzhnev M. ta in. Kyiv: Nika-tsentr. 2010:264. Ukrainian.

12. Velychko S., Tretiakov O. Alternatyvna enerhetyka Ukrainy. Kharkiv: Osnova. 2010:128. Ukrainian.

13. Alternatyvne palyvo - tvoia enerhetychna nezalezhnist. HO "Za chyste dovkillia". Rivne: Druk Volyni, 2011:16. Ukrainian.

14. Tarariko Yu.O. Perspektyvy rozvytku bioenerhetyky v APK. Visnyk ahrarnoi nauky. 2010; 4:9-13. Ukrainian.

15. Heletukha H.H., Zheliezna T.A., Kucheruk P.P., Oliinyk Ye.M. Suchasnyi stan ta perspektyvy rozvytku bioenerhetyky v Ukraini. Analitychna zapyska BAU 9. Bioenerhetychna asotsiatsiia Ukrainy. 2014:32.Ukrainian. Rezhym dostupu: http://uabio.org/img/ files/docs/position-paper-uabio-9-ua.pdf

16. Roik M.V. Perspektyvy rozvytku bioenerhetyky v Ukraini. Tsukrovi buriaky. 2012; 2/3:6-8. Ukrainian.

17. Trypolska H. Ahrobioenerhetychnyi rynok Ukrainy: monohrafiia. Kyiv. 2011:264. Ukrainian. 
18. Kandul S. Polityka stymuliuvannia biopalyva v ES - popyt na ukrainskyi ripak. Propozytsiia. 2010; 6:18-21. Ukrainian.

19. Kandul S. Novi vymohy do biopalyvnoi syrovyny v ES: shcho ochikuvaty ukrainskym ahrariiam. Propozytsiia. 2010; 6:18-21. Ukrainian.

20. Heletukha H., Zheliezna T., Tyshaiev S. ta in. Kontseptsiia rozvytku bioenerhetyky v Ukraini. K. 2001:14. Ukrainian.

21. Maissner F., Ukerdt F. Rozvytok vidnovliuvalnykh dzherel enerhii v Ukraini: potentsial, pereshkody i rekomendatsii shchodo ekonomichnoi polityky. Berlin Economics. Za pidtrymky: Federalnoho ministerstva dovkillia, okhorony pryrody i bezpeky yadernykh reaktoriv; na osnovi rishennia Nimetskoho Bundestahu. Ukrainian.

22. Khivrych O. B., Kvak V. M., Kaskiv V. V. ta in. Enerhetychni roslyny yak alternatyva tradytsiinym vydam palyva. Ahrobiolohiia. 2011;6:153-7.Ukrainian.

23. Roik M.V., Humentyk M.Ia., Mamaisur V.V. Perspektyvy vyroshchuvannia enerhetychnoi verby dlia vyrobnytstva tverdoho biopalyva. Bioenerhetyka. 2013; 2:189. Ukrainian.

24. Khivrych O. Enerhetychna verba — shliakh do nezalezhnoi enerhetyky. Propozytsiia. 2014; 11:76-81. Ukrainian.

25. Smirnov O. Perspektyvy vykorystannia verby prutovydnoi yak vidnovliuvalnoho dzherela biopalyva.Visnyk ahrarnoi nauky. 2013; 4:75-7. Ukrainian.

26. Ivakhiv V. Enerhetychna verba yak rishennia dlia malykh mist Ukrainy [Elektronnyi resurs] / V. Ivakhiv / - Rezhym dostupu: http://ua- energy.org/post/27476. Ukrainian.

27. Fuchylo Ya. Enerhetychni plantatsii verby: vybir vydiv i sortiv dlia yikh stvorennia. Novyny ahrotekhniky. 2013; 3/4:46-7. Ukrainian.

28. Topolia na biopalyvo: osoblyvosti tekhnolohii vyroshchuvannia [Elektronnyi resurs]. Propozytsiia. Holovnyi zhurnal z pytan ahrobiznesu: sait.Ukrainian. Rezhym dostupu: http: //propozitsiya.com/ua/topolya-na-biopalivo-osoblivosti-tehnologiyiviroshchuvannya.

29. Maramorosch K., Raychaudhuri S.P. Mycoplasma Diseases of Trees and Shrubs. Academic Press, New York. 1981.

30. McCoy R.E. Plant diseases assosiated with mycoplasma-like organisms. In: Whitcomb R.F., Tully J.G. The Mycoplasmas. Academic Press, New York.1989:545 - 640.

31. Lee I.-M., Davis R.E., Gundersen-Rindal D.E. Phytoplasma: phytopathogenic mollicutes. Annual Review of Microbiology. 2000; 54:221-55.

32. Braun E.J., Sinclair W.A. Histopathology of phloem necrosis in Ulmus americana. Phytopathology.1976; 66(5):598 - 607.

33. Schneider H. Graft transmission and host range of the pear decline causal agent. Phytopathology.1970; 60(2):204-7.

34. Rosenberger D.A., Jones A.L. Spread of X-disease in Michigan peach orchards. Plant Dis. Reptr. 1971; 61(10):830-34.

35. Weintraub P.G., Beanland L. Insect vectors of phytoplasmas. Ann. Rev. Entomol. 2006; 51:91-111.

36. Berges R., Rot M., Seemuller E. Range of phytoplasma concentrations in various plant hosts as determined by competitive polymerase chain reaction.Phytopathology.2000; 90:1145-52.

37. Vlasov Yu.Y., Henyte L.P., Samsonova L.N. Akholeplazmy - patoheny rastenyi. Mynysterstvo selskoho khoziaistva, Vylnius.1985:77. Russian. 
38. Seemüller E., Garnier M., Schneider B. Mycoplasmas of plants and insects. In: Razin S., Hermann R. (eds) Molecular Biology and Pathogenicity of Mycoplasmas. Kluwer Academic/Plenum Publishers, New York. 2002:9-115.

39. Sinclair W.A., Griffiths H.M. Ash yellows and its relationship to dieback and decline of ash. Ann. Rev. Phytopathol.1994; 32:49-60.

40. Sinclair W.A., Griffiths H.M., Davis R.E. Ash yellows and lilac witch broom: phytoplasmal diseases of concern to forestry and horticulture.Plant Disease.1996; 80:468-75.

41. Lim P.O., Sears B.B. 16S rRNA sequence indicates that plant-pathogenic mycoplasmalike organisms are evolutionarily distinct from animal mycoplasmas. J. Bacteriol.1989; 171:5901-6.

42. Gundersen D.E., Lee I-M., Rehner S.A., Davis R.E., Kingsbury D.T. Phylogeny of mycoplasmalike organisms (phytoplasmas), a basis for their classification. J. Bacteriol.1994; 176:5244-54.

43. Lee I-M., Zhao Y., Bottner K.D. Sec Y gene sequence analysis for finer differentiation of diverse strains in the aster yellows phytoplasma group. Molecular and Cellular Probes.2006; 20: 87-91.

44. Martini M., Lee I-M., Bottner K.D., Zhao Y., Botti S. and other. Ribosomal protein gene-based phylogeny for finer differentiation and classification of phytoplasmas. Int. J. Syst. Evol. Microbiol. 2007; 57:2037-51.

45. Hodgetts J., Boonham N., Mumford R., Harrison N., Dickinson M. Phytoplasma phylogenetics based on analysis of secA and 23S rRNA gene sequences for improved resolution of candidate species of 'Candidatus Phytoplasma'. Int. J. Syst. Evol. Microbiol. 2008; 58:1826-37.

46. Lee I.-M., Hammond R.W., Davis R.E., Gundersen D.E. Universal amplification and analysis of pathogen 16S rRNA for classification and identification of mycoplasmalike organisms. Phytopathology. 1993; 83:834-42.

47. Lee I-M., Gundersen-Rindal D.E., Davis R.E., Batroszyk I.M. Revised classification scheme of phytoplasmas based on RFLP analyses of 16S rRNA and ribosomal protein gene sequences. Int. J. Syst. Bacteriol.1998; 48:1153-69.

48. Lee I.-M., Martini M., Marcone C., Zhu S.F. Classification of phytoplasma strains in the elm yellows group (16SrV) and proposal of 'Candidatus Phytoplasma ulmi' for the phytoplasma associated with elm yellows. Int. J. Syst. Evol. Microbiol. 2004a; 54:33747.

49. Lee I.-M., Gundersen D.E., Davis R.E., Bottner K.D., Marcone C., Seemüller E. 'Candidatus Phytoplasma asteris', a novel phyoplasma taxon associated with aster yellows and related diseases. Int. J. Syst. Evol. Microbiol. 2004b; 54:1037-48.

50. IRPCM Phytoplasma/Spiroplasma Working Team - Phytoplasma Taxonomy Group: 'Candidatus Phytoplasma', a taxon for the wall-less, non-helical prokariotes that colonize plant phloem and insects. International. J. Syst. Evolution. Microbiol. 2004; 54:1243-55.

51. Cvrković T., Jović J., Mitrović M., Petrović A., Krnjajić S., Malembic-Maher S., Toševski, I. First report of alder yellows phytoplasma on common alder (Alnus glutinosa) in Serbia. Plant Pathology. 2008; 57:773.

52. Davis R.E., Dally E.L., Zhao Y., Lee I.-M., Jomantiene R., Detweiler A.J., Putnam M.L. First report of a new subgroup 16SrIX-E ('Candidatus Phytoplasma phoenicium'- 
related) phytoplasma associated with juniper witches' broom disease in Oregon, USA. Plant Pathology. 2010; 59:1161.

53. Griffiths H.M., Gundersen D.E., Sinclair W.A., Lee I.-M., Davis R.E. Mycoplasmalike organisms from milkweed, goldenrod and spirea represent two new $16 \mathrm{~S}$ rRNA subgroups and three new strain subclusters related to peach X-disease MLOs. Can. J. Plant Pathol.1994a; 16:255-60.

54. Griffiths H.M., Sinclair W.A., Davis R.E., Lee I.-M., Dally E.L., Guo Y.-H., Chen T.A., Hibben C.R. Characterization of mycoplasmalike organisms from Fraxinus, Syringa and associated plants from geographically diverse sites. Phytopathology. 1994b; 84:119-26.

55. Griffiths H.M., Sinclair W.A., Boudon-Padieu E., Daire X., Lee I.-M., Sfalanga A., Bertaccini A. Phytoplasmas associated with elm yellows: molecular variability and differentiation from related organisms.Plant Disease.1999a; 83:1101-4.

56. Jacobs K.A., Lee I.-M., Griffiths H.M., Miller F.D., Bottner K.D. A new member of the clover proliferation phytoplasma group (16SrVI) associated with elm yellows in Illinois. Plant Disease. 2003; 87:241-46.

57. Griffiths H.M., Sinclair W.A., Smart C.D., Davis R.E. The phytoplasma associated with ash yellows and lilac witches' broom: 'Candidatus Phytoplasma fraxini'.Int. J. Syst. Bacteriol. 1999b; 49:1605-14.

58. Matteoni J.A., Sinclair W.A. Elm yellows and ash yellows. In: Hiruki, C. (ed.) Tree Mycoplasma Diseases and Epidemiology. University of Alberta, Edmonton, Alberta, Canada. 1988.

59. Mou H.-Q., Xu X., Wang R.-R., Tian Q., Wei Y., Zhu S.-F., Liao X.-L., Zhao W.-J. Salix tetradenia Hand.-Mazz: a new natural plant host of 'Candidatus phytoplasma'. Forest Pathology. 2014; 44 (1):56-61. In: onlinelibrary.wiley.com/doi/10.1111/efp.12068/pdf

60. Wei T, Wu Y, Hou W, Wu K, Li Y, Zhang J, Sun R. Molecular classification of a phytoplasma associated with willow yellow disease / Article in Chinese. 2009; 49 (3):389-94. PubMed PMID: 19630184. https://www.ncbi.nlm.nih.gov/ pubmed/19630184

61. Berges R., Cousin M.-T., Roux J., Maurer R., Seemuller E. Detection of phytoplasma infections in declining Populus nigra 'Italika' trees and molecular differentiation of the aster yellows phytoplasma identified in various Populus species. Eur. J. Forest Pathol.1997; 27:33-43.

62. Seruga M., Skoric D., Botti S., Paltinieri S., Juretic N, Betraccini A. Molecular characterization of a phytoplasma from the aster yellows (16Srl) group naturally infecting Populus nigra L. 'Italika' trees in Croatia. Forest Pathol. 2003; 33:113-25.

63. Music M.S., Novokmet M., Krajacic M., Skoric D. Distribution of phytoplasma diseases in the Lombardy poplar tree population of Zagreb urban area. Acta Botanica Croatia. 2008; 67:119-30.

64. Wei T., Wu Y.F., Wu K.K., Hou W., Li Y.R. First report of a 16SrI-C group phytoplasma associated with yellows-type disease affecting willow plants in China. Plant Disease. 2009; 93: 197.

65. Jomantiene R., Valiunas D., Ivanauskas A., Urbanavieiene L., Staniulis J., Davis R.E. Larch is a new host for a group 16SrI, subgroup B, phytoplasma in Ukraine. Bulletin of Insectology. 2011; 64:101-2. 
66. Lin C.-P., Huang J.-P., Wu C.-S., Hsu C.-Y., Chaw S.-M. Comparative chloroplast genomics reveals the evolution of Pinaceae genera and subfamilies. Genome Biology and Evolution. 2010; 2:504-17.

67. Davis R.E., Dally E.L., Zhao Y., Lee I.-M., Jomantiene R., Detweiler A.J., Putnam M.L. First report of a new subgroup 16SrIX-E ('Candidatus ` Phytoplasma phoenicium 'related) phytoplasma assosiated with juniper witches broom disease in Oregon, USA. Plant Pathology. 2010; 59:1161.

68. Schneider B., Torres E., Martin M., Schroder M., Behnke H.D., Seemuller E. 'Candidatus' Phytoplasma pini', a novel taxon from Pinus sylvestris and Pinus halepensis. Int. J. Syst. Evolution. Microbiol. 2005; 55:303-7.

69. Kamiñska M., Berniak H. 'Candidatus Phytoplasma asteris' in Fraxinus excelsior and its association with ash yellows newly reported in Poland. Plant Pathol. 2009; 58:788.

Отримано 4.04.2018 